\title{
Pemanfaatan Teknologi Probio_Fm dalam Penerapan Sistem Integrasi Sapi Kelapa Sawit di Bangka Tengah
}

\section{(Development of Probio_Fm Technology in the Implementation of the Integration System of Oil Palm in Central Bangka)}

\author{
Yudi Sapta Pranoto, Fournita Agustina, Rufti Puji Astuti* \\ Pogram Studi Agribisnis, Fakultas Pertanian Perikanan dan Biologi, Universitas Bangka Belitung, Jl. Kampus Terpadu UBB, \\ Balunijuk, Merawang, Bangka, Bangka Belitung 33172. \\ *Penulis korespondensi: ruftipuji24@gmail.com \\ Diterima September 2019/Disetujui Mei 2020
}

\begin{abstract}
ABSTRAK
Sistem integrasi sapi dan kelapa sawit merupakan program unggulan pemerintah Bangka Tengah guna meningkatkan produksi hasil perkebunan dan sekaligus produk peternakan. Manfaat penerapan sistem integrasi sapi dan kelapa sawit adalah tersedianya sumber pakan bagi ternak dari limbah pelepah sawit, sebaliknya feses sapi berpotensi menyediakan pupuk untuk tanaman sawit. Tujuan pengabdian ini untuk mengubah cara berfikir masyarakat dalam menyikapi program sistem integrasi sapi kelapa sawit, serta untuk memberdayakan masyarakat pelaku integrasi sapi kelapa sawit dalam menerapkan teknologi probio_Fm. Metode pelaksanaan dilakukan melalui empat tahapan, yaitu persiapan, sosialisasi, demontrasi, serta diakhiri dengan monitoring dan evaluasi. Analisis data dilakukan dengan analisis deskriptif kualitatif. Hasil kegiatan pengabdian menunjukkan bahwa sebanyak $90 \%$ peternak sepakat penerapan integrasi sapi kelapa sawit itu mudah. Peternak pada kelompok tani Tunas Baru telah berdaya dan trampil menggunakan teknologi probio_Fm dalam penerapan sistem integrasi sapi dan kelapa sawit, melalui pembuatan pakan silase pelepah sawit. Kegiatan sosialisasi dan demontrasi yang telah dilakukan berdampak pada perubahan pengetahuan dan perilaku peternak dalam manajemen pakan. Hasil pendampingan yang telah dilakukan menemukan adanya kendala dalam penerapan teknologi probio_Fm sebagai bahan fermentasi pakan silase, yaitu ternak membutuhkan waktu untuk beradaptasi dengan pakan silase pelepah sawit semala 1 minggu. Pemanfaatan mesin pencacah rekayasa bisa menjadi alternatif pilihan, mesin mampu menghasilkan cacahan pelepah lebih halus. Pemanfaatan teknologi probio_Fm dalam penerapan sistem integrasi sapi kelapa sawit pada kelompok tani Tunas Baru berpotensi dapat diterapkan peternak secara berkelanjutan.
\end{abstract}

Kata kunci: integrasi, sapi, sawit, teknologi probio_Fm

\begin{abstract}
The integrated cattle and oil palm system is part of an excellent program of the Bangka Tengah Regency to increase the production of plantation and livestock. The benefit of the system is ensuring the availability of the animal feed derived from oil palm plantation waste while the feces of cattle is potential in producing the fertilizer for oil palm. The community service aims to alter the paradigm of the society on the integrated cattle and oil palm system as well as to empower the people to implement the system. Four steps were used as the methods to implement the programs are preparation; socialization; simulation; and monitoring and evaluation. Qualitative descriptive was employed to analyze the data. The program found that $90 \%$ of stock farmers agreed that the system was easily doable. The stock farmers were able to use the probio_Fm technology in implementing the system by making the silage made from the oil palm plantation waste. The knowledge of beneficiaries had increased and their behavior in feeding activities had positively altered through the program. It was found that the livestock required a week to adapt to the silage as the fermented materials in the probio-Fm technology. The use of a chopping machine was able to be a choice as it was able to produce the smoother chopped midrib. It concludes that the system is sustainably used to be implemented by Tunas Baru stock farmer.
\end{abstract}

Keywords: cattle, integration, oil palm, probio_Fm technology

\section{PENDAHULUAN}

Pemerintah Kabupaten Bangka Tengah optimis mengandalkan subsektor perkebunan dan peternakan dalam mewujudkan masyarakat sejahtera berbasis ekonomi kerakyatan dan berkelanjutan. Sistem integrasi sapi kelapa sawit (Siska) merupakan salah satu program 
unggulannya. Pemerintah dalam hal ini mengedepankan peran penguasaan dan pengembangan iptek dalam penerapan Siska dan menargetkan 30 kelompok yang menerapkan teknologi pada tahun 2019. Pemerintah optimis penerapan Siska mampu meningkatkan produksi hasil perkebunan dan sekaligus produk peternakan. Penerapan Siska oleh pelaku integrasi dilakukan dengan model yang berbeda-beda di setiap daerah, disesuaikan dengan kondisi dan kebutuhan. Perapan Siska di Bangka Tengah dilakukan dengan model semi intensif. Konsep utama penerapan Siska adalah mengelola usaha tani sapi dengan memanfaatkan limbah perkebunan sawit sebagai sumber bahan pakan, sebaliknya kotoran dari ternak sapi dijadikan pupuk untuk tanaman sawit (Tiesnamurti et al. 2014).

Subsektor perkebunan dan peternakan memiliki peran yang startegis dalam mendukung program integrasi sapi kelapa sawit. Ketersedian bahan pakan ternak sapi sangat melimpah, berbading lurus dengan perkembangan luasan perkebunan kelapa sawit. Potensi pemanfaatan limbah pelepah sawit sebagai bahan pakan menurut Rizali et al. (2018) dapat dilihat dari kemampuan 1 ha lahan sawit berkontribusi dalam penyediaan limbah pelepah. Jika dalam 1 ha lahan perkebunan kelapa sawit diasumsikan terdapat 130 pohon kelapa sawit, dan kemampuan setiap pohon menghasilkan pelepah pertahun adalah 22-26 pelepah dengan berat rata-rata 4-6 kg/pelepah, maka dari 1 ha lahan akan tersedia limbah pelepah sebanyak 2,3 ton bahan kering. Pakan berbahan dasar pelepah dan daun sawit tidak hanya mudah dibuat, ketersediaan bahan melimpah, tetapi juga memiliki nilai gizi yang baik untuk ternak. Kandungan zatzat nutrisi pelepah dan daun sawit adalah bahan kering sebanyak $48,78 \%$, protein kasar sebanyak $5,3 \%$, hemiselulosa sebanyak $21,1 \%$, selulosa sebanyak 27,9\%, serat kasar sebanyak 31,09\%, abu sebanyak 4,48\%, BETN sebanyak 51,87\%, lignin sebanyak $16,9 \%$, dan silika sebanyak $0,6 \%$ (Imsya 2007).

Pengembangan sektor peternakan pada umumnya terkendala pada masalah penyediaan pakan ternak. Adriani et al (2016) menyatakan permasalahan yang dihadapi peternak di Kabupaten Tanjung Jabung Timur dalam kegiatan budi daya ternak adalah penyediaan pakan yang berkualitas, kontinu, dan bisa disimpan dalam waktu yang lama. Pada kenyataanya pakan itu murah, melimpah, dan mudah diperoleh, jika sistem integrasi sapi kelapa sawit benar-benar diterapkan dan diperkuat dengan penguasaan IPTEK oleh peternak.

Kelurahan Sungai Selan ditetapkan sebagai kelurahan percontohan untuk penerapan sistem integrasi sapi kelapa sawit, tepatnya di kelompok tani Tunas Baru. Kelompok Tani Tunas Baru diketuai oleh bapak Nur Rohim dengan 32 anggota dan jumlah kepemilikan ternak 183 ekor. Kelompok terus melakukan inovasi bersama mahasiswa KKN, dan saat ini peternak telah menguasai teknologi probio_FM yang digunakan untuk pengolahan pakan silase pelepah sawit. Penggunaan teknologi probio_FM menjadikan penerapan sistem integrasi sapi kelapa sawit di kelompok tunas baru, tidak hanya mudah, tetapi juga efisien dalam manajemen waktu. Teknologi probio_FM dinilai sederhana dan tepat guna dalam mendukung program sitem integrasi sapi kelapa sawit. Probio_Fm bisa digunakan sebagai bahan tambahan dalam pengolahan pakan hijauan fermentasi, seperti pelepah kelapa sawit. Pakan hijaun fermentasi yang diolah menggunakan teknologi probio_Fm terbukti memengaruhi perubahan bobot badan ternak sapi bali, dengan peningkatan mencapai 0,9-1,1 $\mathrm{kg} /$ hari (Novianti \& Adriani 2012).

Probio_Fm merupakan probiotik cair mengandung beberapa spesies bakteri asam laktat, yang merupakan hasil isolasi mikroba, diambil dari saluran pencernaan itik Kerinci (Manin et al. 2003; Manin et al. 2010). Teknologi probio_Fm memiliki cara kerja menekan jumlah mikroba patogen dalam saluran pencernaan. Teknologi probio_Fm dapat digunakan dalam pembuatan pakan ternak ruminansia maupun unggas. Aplikasi pakan berbasis teknologi probio_Fm pada ternak terbukti mengurangi jumlah bakteri patogen pada saluran pencernaan unggas, meningkatkan produktivitas ternak itik dan sapi, meningkatkan kesehatan ternak, mengatasi permasalahan pencemaran bau kandang, serta meningkatkan efisiensi penggunaan pakan (Fuller 2002; Manin et al. 2003; Yusrizal \& Aziz 2009; Hendalia et al. 2010; Manin et al. 2010; Hendalia et al. 2012; Yusrizal et al. 2012; Manin et al. 2014; Riza et al 2015, Hendalia et al. 2017)

Keberhasilan kelompok Tunas Baru dalam menerapkan Siska belum dapat merepresentasikan keberhasilan pelaksanaan program secara keseluruhan. Masih ditemukan adanya kelompok yang memelihara sapi dan memiliki kebun sawit, namun belum menerapkan Siska di Kelurahan Sungai Selan. Masalah utamanya adalah penguasaan teknologi rendah, serta cara 
pandang masyarakat bahwa penerapan Siska sulit untuk dilakukan, biaya mahal, dan menyita waktu.

Mengingat besarnya dukungan potensi sebagaimana diuraikan di atas, serta keberadaan kelompok Tunas Baru turut berperan penting memengaruhi masyarakat, maka transformasi cara berfikir masyarakat ini sangat diperlukan. Tranformasi diarahkan pada cara berfikir untuk tercapainya pemberdayaan masyarakat di Kelurahan Sungai Selan dalam rangka penggunaan teknologi probio_Fm, dalam penerapam Siska. Kegiatan ini dikemas malaui program Kuliah Kerja Nyata Pembelajaran Pemberdayaan Masyarakat (KKNPPM) dilakukan dalam rangka penyebarluasan teknologi probio_Fm. Wujud penyelesaian masalah akan dilakukan melalui pendampingan masyarakat dengan menerapkan sistem induk semang. Tujuan kegiatan pengabdian ini adalah untuk mengubah cara berfikir masyarakat dalam menyikapi program sistem integrasi sapi kelapa sawit, serta untuk memberdayakan masyarakat pelaku integrasi sapi kelapa sawit dalam menerapkan teknologi probio_Fm

\section{METODE PELAKSANAAN KEGIATAN}

\section{Waktu dan Tempat}

Pengabdian dilaksanakan selama 40 hari, mulai 12 Juli-20 Agustus 2019 di wilayah swadaya Kelurahan Sungai Selan, Kecamatan Sungai Selan, Kabupaten Bangka Tengah, Bangka Belitung. Pemilihan lokasi KKN dilakukan atas pertimbangan bahwa Kelurahan Sungai Selan merupakan desa percontohan untuk program sistem integrasi sapi kelapa sawit (Siska).

\section{Alat dan Bahan}

Alat yang digunakan dalam pelaksanaan program adalah mesin pencacah, parang, terpal, drum. Bahan yang digunakan dalam pelaksanaan program ini adalah pelepah sawit, dedak, molases, probio_Fm F3, plastik, tali, dan air.

\section{Prosedur Kerja}

Prosedur kerja pembuatan pakan silase pelepah sawit dengan teknologi probio_Fm adalah 1) mempersiapkan alat dan bahan; 2) Mencacah pelepah sawit; 3) Menimbang bahan berupa cacahan pelepah, dedak, molases, probio_Fm F3; 4) Mencampur bahan cacahan pelepah, dedak, dan molases sampai homogen; 5) Menambahkan probio_Fm F3 dengan memercikkan larutan di atas campuran bahan; 6) Mengaduk bahan sampai homogen; 7) Bahan dimasukan dalam wadah drum/kantong plastik dan ditutup kedap udara; 8) Pemanenan hasil fermentasi pakan setelah 1 minggu; dan 9) Pakan silase siap diberikan pada ternak.

\section{Bentuk Kegiatan}

Bentuk kegiatan yang dilakukan meliputi persiapan program, sosialisasi, demonstrasi pembuatan mesin pencacah rekayasa, dan pembuatan pakan silase, serta monitoring dan evaluasi. Tujuan dari kegiatan persiapan dan sosialisasi program adalah untuk memastikan kesesuaian program dengan penerimanya, kesiapan penerima program, kesesuaian jadwal, dan kelancaran pelaksanaan program. Kegiatan demontrasi dilakukan setelah peserta memahami materi, tujuan kegiatan demontrasi agar peserta memiliki pengalaman praktik merakit mesin pencacah maupun cara pemanfaatan probio_Fm dalam mengolah pakan silase pelepah sawit. Monitoring dan evaluasi merupakan kegiatan tahap akhir, bertujuan untuk memastikan keberlanjutan program dengan mengamati berbagai kendala yang dihadapi peserta dalam menerapkan teknologi.

\section{Metode Pengumpulan dan Analisis Data}

Metode pengumpulan data dalam pelaksanaan program adalah dengan wawancara dan penyebaran angket (lembar observasi). Jenis data yang dikumpulkan adalah data primer, terdiri dari data minat peternak, kesesuaian materi pelatihan, penilaian peternak pada mesin pencacah rakitan, dan data ketercapaian materi pelatihan. Analisis data menggunakan metode deskriptif kualitatif.

\section{HASIL DAN PEMBAHASAN}

Pelaksanaan program pengabdian masyarakat dilakukan secara sistematis melaui 4 tahapan, yaitu persiapan, sosialisasi kegiatan dan materi, demonstrasi, serta monitoring dan evaluasi kegiatan.

\section{Persiapan}

Persiapan merupakan tahap awal pelaksanaan program, pada tahap ini tim pengabdi bersama perwakilan mahasiswa KKN-PPM UBB melakukan survei lokasi. Kegiatan survei lokasi selain untuk memastikan lokasi posko, juga untuk memastikan kondisi dan permasalahan 
yang dihadapi masyarakat Kelurahan Sungai Selan. Persiapan dilanjutkan dengan kegiatan focus group discussion (FGD), bertempat di rumah ketua Kelompok Tunas Baru, dengan peserta sebanyak 11 orang yang terdiri dari Ketua Lingkungan Swadaya Sungai Selan, Ketua Tunas Baru, Ketua Kelompok Nelayan Mandiri, Dosen Pembimbing Lapangan serta mahasiswa peserta KKN PPM. Kegiatan FGD dilakukan untuk menyampaikan program KKN, metode pelaksanaan program, dan kriteria masyarakat sasaran (Gambar 1).

Hasil kegiatan FGD diantaranya, lokasi swadaya dipilih sebagai lokasi pelaksanaan program KKN. Pelaksanaan program KKN dilakukan dengan penerapan metode induk semang, dan disepakati terdapat 4 masyarakat sasaran yang akan dijadikan induk semang. Kesepakatan pemilihan induk semang berdasarkan kriteria bahwa petani tersebut memiliki ternak sapi dan kebun sawit, induk semang pernah mengolah pelepah sawit namun tidak berkelanjutan karena terkendala mesin pencacah dan belum menguasai teknologi pengolahan pakan. Hasil kegiatan FGD juga menunjukkan adanya kesepakatan jadwal pendampingan dengan induk semang maupun kelompok tunas baru sebagai kelompok percontohan.

\section{Sosialisasi}

Materi sosialisasi yang disampaikan adalah dampak keberadaan limbah pelepah sawit yang tidak dimanfaatkan pada lingkungan, nilai tambah pelepah sawit sebagai pakan, dan sistem integrasi sapi kelapa sawit (Siska). Kegiatan sosialisasi bertujuan untuk mentransfrer teknologi maupun mengubah cara pandang mereka dalam penerapan sistem integrasi sapi dan kelapa sawit. Kegiatan sosialisasi melibatkan 60 orang peserta yang terdiri dari induk semang, masyarakat Sungai Selan sebanyak 25 orang sekaligus anggota kelompok Tunas Baru, peserta KKN sebanyak 30 mahasiswa, ketua kelompok Tunas Baru, aparatur pemerintahan Kecamatan Sungai Selan sebanyak 5 orang, yaitu lurah dan camat dari Kelurahan Sungai Selan (Gambar 2).

Potensi limbah pelepah sawit sebagai pakan belum dimanfaatkan oleh sebagian besar masyarakat Kelurahan Sungai Selan. Masyarakat di wilayah swadaya biasanya membuang dengan menumpuk pelepah di sekitar kebun sawit, atau membuang ke sungai. Perilaku masyarakat membuang sampah pelepah ke sungai berdampak pada bencana banjir yang terjadi di tahun 2016. Melalui kegiatan KKN, mahasiswa mengajak masyarakat untuk menjaga sungai agar bebas dari limbah pelepah sawit, dengan cara memanfaatkan pelepah sawit menjadi pakan. Mahasiswa juga mensosialisasikan tentang nilai tambah pelepah sawit sebagai pakan kepada masyarakat. Penggunaan pelepah sawit untuk pakai silase secara tidak langsung membantu petani menyediakan pakan berkualitas dan murah.

Kegiatan sosialisasi diakhiri dengan penyampaian materi tentang penerapan sistem integrasi sapi dan sawit, oleh ketua kelompok tani Tunas Baru (Gambar 3). Isi materi yang disampaikan berdasarkan pengalaman, bahwa integrasi sapi

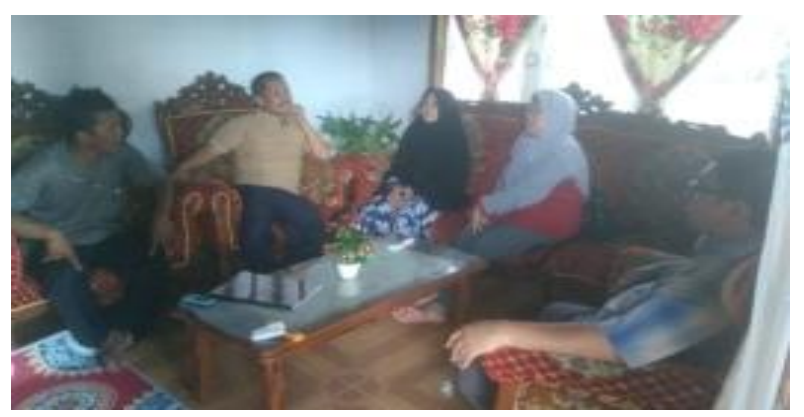

Gambar 1 Kegiatan persiapan survei lokasi dan FGD Persiapan.

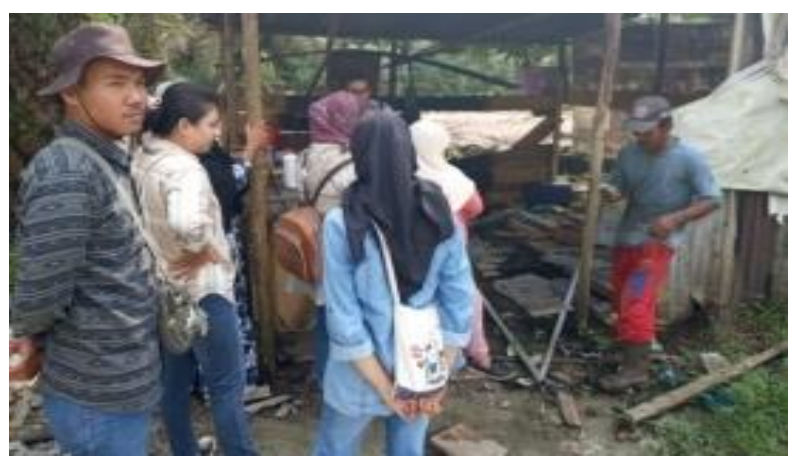

Gambar 2 Sosialisasi kegiatan melibatkan induk semang, masyarakat Sungai Selan, peserta KKN, kelompok Tunas Baru, lurah, dan Camat Sungai Selan.

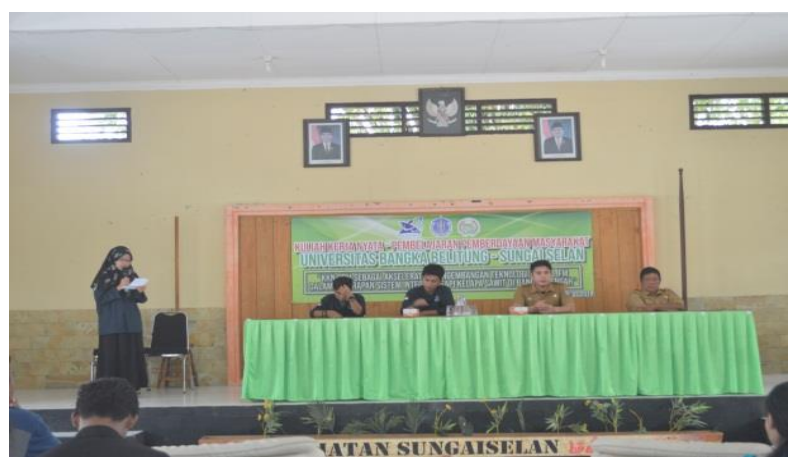

Gambar 3 Penyampaian materi tentang penerapan sistem integrasi sapi dan sawit, oleh ketua kelompok tani Tunas Baru. 
sawit itu mudah, jika petani menguasai teknologinya. Hasil kegiatan sosialisasi menunjukkan adanya perubahan minat dan perilaku sebagain masyarakat swadaya dalam penanganan limbah pelepah. Agar masalah keberadaan limbah pelepah tidak mencemari lingkungan, mahasiswa bersama masyarakat malakukan gotong royong membersihkan lingkungan sungai. Selain itu, hasil kegiatan sosialisasi ini menumbuhkan semangat dan motivasi peternak dalam memanfaatkan limbah pelepah untuk diolah menjadi pakan.

Hasil wawancara kuesioner menunjukkan salah satu faktor penyebab masyarakat belum memanfaatkan pelepah sawit sebagai pakan adalah belum memiliki keterampilan mengolah pakan dan tidak memiliki mesin pencacah pelepah, atau tidak memiliki ternak sapi. Masyarakat yang terpilih menjadi induk semang sebanyak 4 peternak atau $100 \%$ menyatakan setuju juga berminat untuk mengikuti pelatihan pengolahan pakan silase pelepah sawit dan memiliki mesin pencacah (Tabel 1). Langkah awal dalam merespons minat masyarakat, mahasiswa melaksanakan program sehari sekolah lapang dengan berkunjung dan melihat langsung kegiatan pengolahan pakan silase di kelompok Tunas Baru.

\section{Demonstrasi}

Pelaksanaan kegiatan pengabdian tahap ini terdiri dari dua bentuk kegiatan demontrasi, yaitu 1) Demonstrasi perakitan dan pengoperasian mesin pencacah pelepah sawit dan 2) Pendampingan dan pelatihan membuat cacahan pelepah sawit menjadi pakan silase pelepah sawit menggunakan teknologi probio_Fm (Gambar 4).

\section{- Demonstrasi perakitan mesin pencacah}

Program peningkatan keterampilan merakit mesin pencacah pelepah merupakan salah satu program unggulan KKN di Kelurahan Sungai Selan. Program ini bertujuan agar masyarakat khususnya induk semang yang didampingi mampu merakit mesin secara mandiri, dapat mengolah pakan silase pelepah sawit berkelanjutan. Pemerintah Kabupaten Bangka Tengah memiliki program bantuan mesin pencacah pelepah sawit, namun keterbatasan jumlah mesin dibandingkan jumlah penggunanya, menyebabkan kelompok-kelompok yang baru memulai belum memperoleh bantuan mesin pencacah.

Program merakit mesin pencacah pelepah sawit juga bertujuan menyediakan mesin pencacah pelepah sawit yang harganya relatif murah, namun hasil cacahan pelepah sawit tetap berkualitas. Mahasiswa dan tim pengabdi mengadopsi desain mesin pencacah pabrikan yang ada di kelompok Tunas Baru. Proses perakitan melibatkan mahasiswa teknik mesin dan masyarakat, dilakukan selama 25 hari kerja.

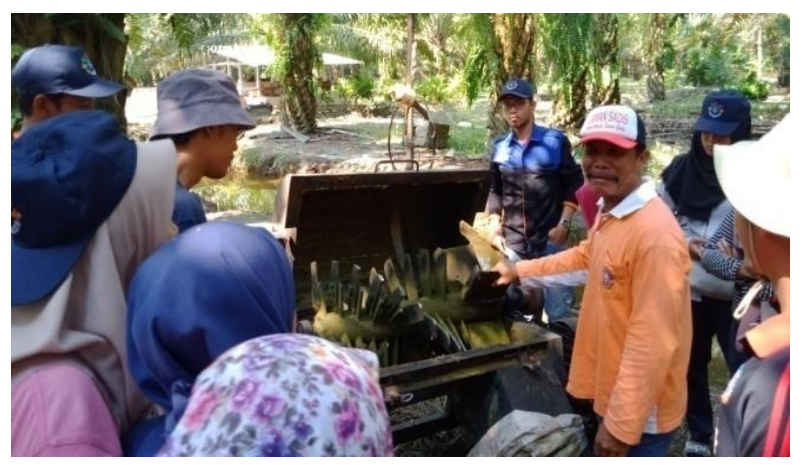

Gambar 4 Pendampingan dan pelatihan membuat cacahan pelepah sawit menjadi pakan silase pelepah sawit.

Tabel 1 Hasil wawancara kuesioner kepada induk semang

\begin{tabular}{lcc}
\hline \multicolumn{1}{c}{ Indikator penilaian } & Jumlah & Persentase \\
\hline Minat & 4 & 100 \\
Mengikuti pelatihan pembuatan pakan silase pelepah sawit & 4 & 100 \\
Minat memiliki mesin pencacah & 2 & 50 \\
Penialain terhadap materi pelatihan & 4 & 100 \\
Materi mudah dipahami peternak & 4 \\
Materi dibutuhkan peternak & 4 & 100 \\
Penilaian terhadap keunggulan mesin pencacah & 2 & 50 \\
Hasil cacahan pelepah lebih halus & 4 & 100 \\
Kapasistas mesin lebih besar & 4 & 100
\end{tabular}


Harga mesin pencacah rakitan ini adalah $\mathrm{Rp}$ 17.767.000, relatif lebih murah dibandingkan mesin pabrikan. Mesin hasil rakitan diserahkan kepada induk semang dan diresmikan langsung oleh Bupati Bangka Tengah (Gambar 5). Hasil wawancara kuesioner pada Tabel 1 menunjukan secara keseluruhan induk semang sepakat menyatakan mesin pencacah pelepah rekayasa memberi hasil cacahan pelepah sawit dengan tingkat kehalusan 2 kali dari mesin pabrikan (Gambar 6).

\section{- Demonstrasi pembuatan pakan silase pelepah sawit}

Kegiatan demontrasi dilanjutkan dengan pelatihan pembuatan pakan silase pelepah sawit menggunakan teknologi probio_Fm. Tujuan utama tim pengabdi memberdayakan peternak menggunakan teknologi probio_Fm dalam pembuatan pakan silase pelepah sawit adalah, agar peternak mampu menyediakan pakan berkualitas, tersedia terus menerus, dan dapat disimpan dalam waktu yang lama. Pelatihan pembuatan pakan silase pelepah sawit oleh mahasiswa peserta KKN, dilakukan sebanyak 2 kali. Demontrasi pelatihan pembuatan pakan silase pelepah sawit dengan teknologi probio_Fm mahasiswa dibimbing ketua kelompok Tunas Baru serta dihadiri langsung oleh pakar sebagai narasumber. Demontrasi pelatihan pembuatan pakan silase pelepah sawit, dilakukan dengan cara mahasiswa mendampingi induk semang untuk mencoba mempraktikkan secara mandiri membuat pakan silase pelepah sawit (Gambar 7).

Proses pembuatan pakan silase pelepah sawit berbasis probio_Fm dilakukan melaui 5 tahapan diawali dengan persiapan alat dan bahan, pencampuran, pengadukan, fermentasi bahan, dan pemanenan. Alat yang digunakan untuk proses pembuatan pakan silase pelepah sawit adalah mesin pencacah pelepah salit, trash bag, timbangan, drum plastik, baskom atau ember, tali, dan terpal. Bahan yang digunakan adalah pelepah sawit, bungkil inti sawit, molases, garam, kapur dolomit, polar atau dedak, dan probiotik probio_Fm F3. Pembauatan pakan silase pelepah sawit melibatkan berbagai bahan pakan pendamping. Penggunaan kombinasi bahan pakan bertujuan untuk meningkatkan kualitas pakan berdasarkan kelengkapan nilai nutrisi pakan. Penggunaan pelepah dan daun sawit sebagai pakan tunggal memiliki keterbatasan, sehingga untuk meningkatkan kualitas pakan yang dihasilkan serta untuk memenuhi kebutuhan nutrisi sapi potong, penggunaan pelepah sawit

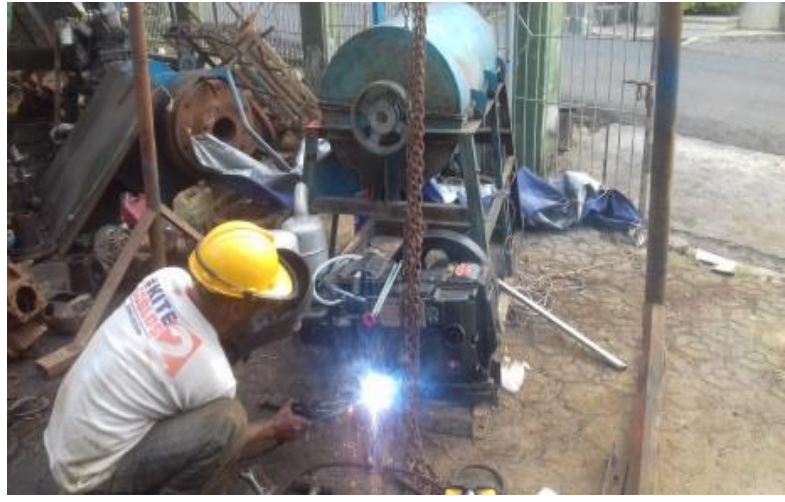

a

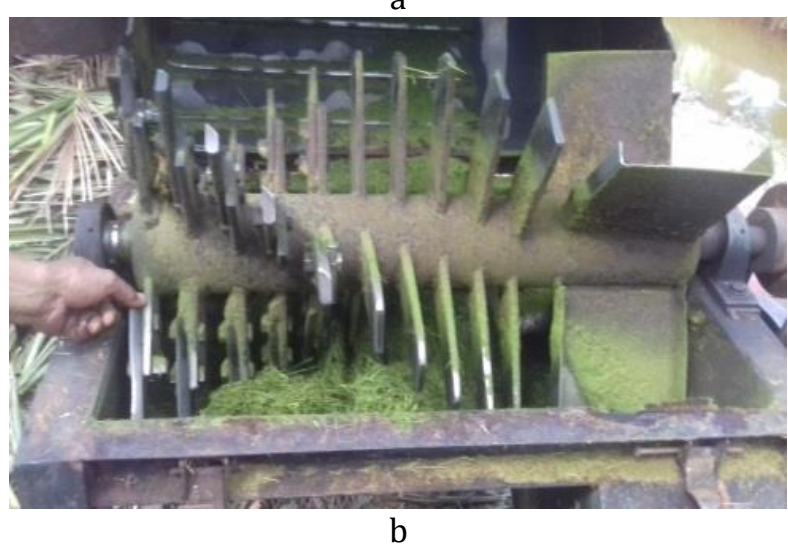

Gambar 5 a) Proses perakitan mesin dan b) Mesin hasil rakitan.

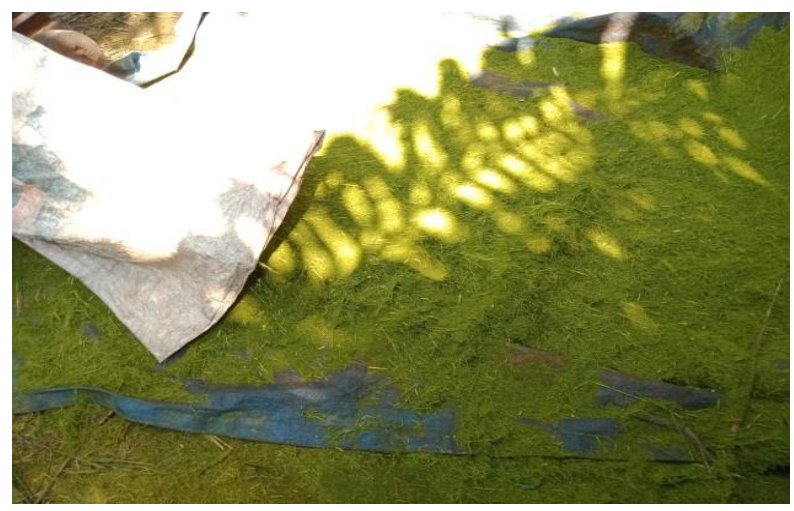

Gambar 6 Hasil cacahan pelepah sawit dengan tingkat kehalusan dua kali dari mesin pabrikan.

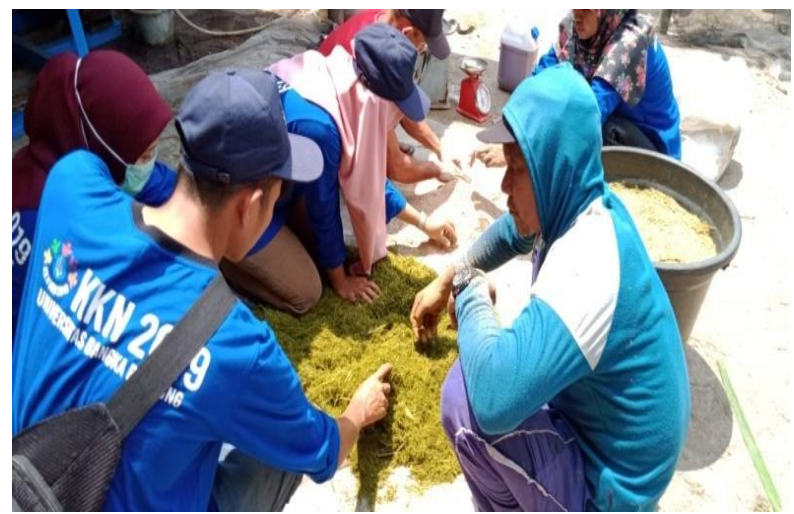

Gambar 7 Pendampingan praktik secara mandiri membuat pakan silase pelepah sawit. 
perlu dikombinasikan dengan bahan pakan lainnya (Noel 2003; Kuswandi 2011).

Bungkil inti sawit (BIS) adalah hasil samping dari proses pengolahan inti sawit dalam proses produksi minyak inti sawit. Bungkil inti sawit digunakan sebagai bahan campuran dalam proses pembuatan pakan silase pelepah sawit karena bahan tersebut memiliki nilai gizi, yaitu kandungan serat kasar sekitar 37\% (Gunawan \& Thalib 2014). Penggunaan bungkil inti sawit dalam proses pembuatan pakan silase pelepah sawit karena ketersediaan bahan di lokasi KKNPPM melimpah dan mudah diakses peternak. Harga BIS di lokasi pelaksanaan KKNPPM ini adalah Rp 1600/kg. Penggunaan BIS sebagai bahan pakan dinilai sangat potensial, namun permasalahannya bahan pakan yang bernilai gizi tersebut sudah banyak diekspor (Gunawan \& Thalib 2014). Solusi penggunaan bungkil inti sawit dalam pembuatan pakan silase pelepah sawit dapat digantikan dengan penggunaan bungkil kelapa (Adriani et al. 2016).

Proses pembuatan pakan silase pelepah sawit diawali dengan penggilingan pelepah sawit sebanyak $10 \mathrm{~kg}$ menggunakan mesin pencacah (shredder). Bahan yang ditimbang adalah bungkil inti sawit sebanyak $2,5 \mathrm{~kg}$, polar atau dedak $2 \mathrm{~kg}$, molases $100 \mathrm{~mL}$, garam 1 ons, kapur 1 ons, dan probiotik probio_Fm F3 sebanyak $250 \mathrm{~mL}$. Kegiatan penimbangan bahan dilakukan oleh mahasiswa menggunakan timbangan manual, sedangkan bahan molases, dan probiotik probio_Fm diukur menggunakan gelas aqua ukuran $250 \mathrm{~mL}$. Proses penimbangan dilakukan dihadapan peternak yang hadir, dengan tujuan agar peternak memperoleh pengetahuan tentang kombinasi ukuran bahan yang digunakan.

Proses pembuatan pakan silase dilanjutkan pada tahap pencampuran dan pengadukan bahan. Aktivitas pada tahap ini dilakukan dengan meletakan cacahan pelepah sawit di atas trash bag. Selanjutnya bungkil inti sawit dan polar dimasukan kedalam baskom, dicampur, dan diaduk sampai rata, terakhir tambahkan molases sambil terus diaduk hingga rata kembali. Proses pembuatan pakan silase dilanjutkan dengan mencampurkan cacahan pelepah sawit, bungkil inti sawit, polar, dan molases. Tahapan terakhir dalam proses pencampuran bahan adalah dengan menambahkan garam, kapur, dan menyiramkan probiotik probio_Fm pada tumpukan bahan. Proses pengadukan terus dilakukan sampai semua bahan tercampur rata. Lama waktu yang dibutuhkan untuk mengaduk $15 \mathrm{~kg}$ bahan adalah 15 menit.
Proses pembuatan pakan silase diakhiri dengan kegiatan fermentasi dan pemanenan. Proses fermentasi dilakukan dengan cara semua bahan pakan yang telah tercampur rata dimasukkan kedalam drum plastik, ditutup rapat menggunakan terpal dan diikat menggunakan tali. Proses fermentasi dilakukan selama 14-21 hari, dengan memastikan kondisi drum tetap tertutup rapat. Proses akhir adalah pemanenan pakan silase pelepah sawit, dengan cara membuka tali dan terpal, selanjutnya drum dibiarkan terbuka selama 1 malam untuk mengurangi gas yang dihasilkan dari proses fermentasi, selanjutnya pakan siap diaplikasikan.

Hasil wawancara kuesioner pada Tabel 1 diketahui sebanyak $50 \%$ atau sebanyak 12 orang peserta menyatakan setuju bahwa materi demontrasi pembuatan pakan silase pelepah sawit mudah dipahami. Peserta juga memperoleh pengetahuan tentang cara pembuatan pakan silase pelepah sawit dengan teknologi probio_Fm, dari kegiatan demontrasi yang dilakukan. Peserta demontrasi pelatihan pembuatan pakan silase dipilih 4 orang sebagai induk semang untuk mendapat pendampingan tahap kedua. Hasil pendampingan menemukan adanya respons positif ditunjukkan oleh $100 \%$ atau sebanyak 4 induk semang yang menyatakan setuju bahwa peternak saat ini sudah trampil membuat pakan silase pelepah sawit menggunakan teknologi probio_Fm. Dengan keterampilan yang dimiliki, peternak mampu mempraktikkan membuat pakan silase pelepah sawit di rumah masingmasing.

\section{Monitoring dan Evaluasi}

Monitoring dan evaluasi dilakukan selama 20 hari kerja. Pelaksanaan kegiatan monitoring dan evaluasi dilakukan melalui kegiatan tatap muka, maupun komunikasi melalui media sosial (whatsapp). Pelaksanaan monitoring dan evaluasi dilakukan oleh mahasiswa maupun tim dosen pengabdi dibantu ketua kelompok Tunas Baru. Tujuan kegiatan monitoring dan evaluasi untuk mengamati temuan di lapangan terkait kendala, hasil, dan keberlanjutan program. Hasil monitoring dan evaluasi akan digunakan sebagai dasar dilakukannya perbaikan baik pada perakitan mesin pencacah maupun dalam pengolahan pakan ternak.

Hasil observasi di lapangan menunjukkan adanya beberapa kendala dalam penggunaan mesin pencacah rekayasa. Peternak menyatakan hasil cacahan pelepah sawit sulit untuk keluar dari mesin secara otomatis, menyebabkan mesin 
tersumbat, mengeluarkan asap serta cepat panas. Akibatnya peternak membutuhkan waktu lebih lama untuk menggiling semua pelepah, dan solar yang digunakan juga bertambah. Hasil evaluasi tim KKN pada kendala tersebut, diketahui bahwa faktor penyebab terjadinya penyumbatan adalah struktur pemasangan mata pisau yang kurang simetris. Mesin pencacah kembali diuji coba setelah dilakukan perbaikan, hasil menunjukkan mesin pencacah dapat dioperasionalkan dengan baik tidak ada penyumbatan, hasil cacahan halus serta mampu menggiling pelepah sebanyak 100 $\mathrm{kg} /$ hari. Bentuk keberlanjutan program perakitan mesin pencacah dilakukan oleh salah satu mahasiswa peserta KKNPPM dari jurusan teknik mesin yang menggunakan mesin pencacah rekayasa sebagai objek penelitian dalam penyusunan skripsi.

Hasil monitoring dan evaluasi kegiatan pembuatan pakan silase pelepah sawit oleh induk semang menunjukkan tidak ditemukan adanya kendala, karena induk semang trampil membuat pakan silase pelepah swait. Kendala ditemukan pada proses pemberian pakan silase pelepah sawit ke ternak. Peternak menyatakan bahwa awal pemberian pakan silase pelepah sawit tidak disukai ternak, hal ini disebabkan oleh ternak terbiasa dengan pakan rumput alami. Waktu yang dibutuhkan ternak untuk beradaptasi dengan jenis pakan silase pelepah ini adalah satu minggu. Pemberian pakan silase pelepah sawit pada ternak setelah 1 minggu berdampak pada nafsu makan meningkat. Pelatihan pembuatan pakan silase pelepah sawit juga berdampak pada perubahan perilaku peternak dalam manajemen pemberian pakan ternak, secara keseluruhan peternak sepakat beralih menggunakan pakan silase pelepah dan menerapkan secara berkelanjutan. Ketersediaan pakan pelepah menurut peternak dapat menggantikan pakan rumput. Hal yang sama juga dikemukakan Mathius et al. (2004a), bahwa Pelepah dan daun sawit segar dapat digunakan sebagai pakan ternak pengganti rumput sebanyak 30\% dalam ransum sapi potong. Penyediaan pakan dilakukan dalam satu hari untuk mencukupi kebutuhan pakan selama 10 hari, peternak menyatakan memiliki banyak waktu karena tidak perlu mencari rumput setiap hari.

\section{SIMPULAN}

Penerapan teknologi probio_Fm dalam pengolahan pakan silase pelepah sawit men- jadikan penerapan sistem integrasi sapi kelapa sawit menjadi mudah dan efisien waktu. Peternak induk semang pelaku integrasi sapi kelapa sawit secara keseluruhan trampil mengoprasionalkan mesin pencacah dan membuat pakan silase pelepah sawit dengan teknologi probbio_Fm.

\section{UCAPAN TERIMA KASIH}

Ucapan terima kasih disampaikan kepada Kemenristek Dikti yang telah memberi pendanaan untk pelaksanaan kegiatan pengabdian masyarakat melalui hibah program Kuliah Kerja Nyata Pembelajaran Pemberdayaan Masyarakan (KKNPPM) tahun 2019, kepada Universitas Bangka Belitung (UBB) yang telah memberi kesempatan kepada saya untuk mengikuti pendampingan penyusunan proposal pengabdian masyarakat tahun 2019, serta kepada Universitas Jambi (Unja) atas dukungan pengiriman bahan dan tranfer teknologi yang diberikan. Kepada Dinas Pertanian Bangka Tengah atas izin dan dukungan menugaskan penyuluh lapangan mendampingi pelaksanaan program. Serta Kepada kelompok tani tunas baru dan masyarakat swadaya atas kesediaan dan kerjasamanya menjadi mitra.

\section{DAFTAR PUSTAKA}

Adriani, Fatati, Suparjo. 2016. Aplikasi pakan fermentasi berbasis hijauan lokal pada peternakan sapi di kecamatan geragai Kabupaten Tanjung Jabung Timur. Jurnal Pengabdian pada Masyarakat. 31(3): 1-8.

Fuller R. 2002. Probiotic-What they are and what they do. [Internet]. [diunduh 2018 November 28]: Tersedia pada: https://digestivedisorders/what-are-probiotics.

Gunawan,Talib. 2014. Potensi Pengembangan Bioindustri dalam Sistem Integrasi Sapi Sawit. Wartazoa. 14(02): 67-74.

Hendalia E, Yusrizal, Manin F. 2010. Pemanfaatan Berbagai Spesies Bakteri Bacillus dan Lactobacillus dalam Probiotik untuk Mengatasi Polusi Lingkungan Kandang Unggas. Jurnal Penelitian Universitas Jambi. 12(3): 26-32.

Hendalia E, Manin F, Yusrizal, Nasution GM. 2012. Aplikasi probiotik untuk meningkatkan 
efisiensi penggunaan protein dan menurunkan emisi amonia pada ayam broiler. Agrinak. 1(2): 29-35.

Hendalia E, Manin F, Asra R, Helda H. 2017. Aplikasi Probio_FM Plus melalui Air Minum pada Ayam Broiler di Politani Kupang. Jurnal Ilmu-Ilmu Peternakan. 20(1): 33-38.

Imsya A. 2007. Konsentrasi $\mathrm{N}$-amonia, kecernaan bahan kering dan kecernaan bahan organik pelepah sawit hasil amoniasi secara in vitro. Dalam: Prosiding Seminar Teknologi Peternakan dan Veteriner, 21-22 Agustus 2007. Bogor (ID): Puslitbang Peternakan Badan Litbang Pertanian, Deptermen Pertanian Bogor.

Kuswandi. 2011. Teknologi pemanfaatan pakan lokal untuk menunjang peningkatan produksi. Pengembangan Inovasi Pertanian. 4(3): 189204.

Manin F, Hendalia E, Yatno, Kompiang IP. 2003. Potensi Saluran Pencernaan Itik Lokal Kerinci Sebagai Sumber Probiotik dan Implikasinya Terhadap Produktivitas Ternak dan Penanggulangan kasus Salmonellosis. Laporan Penelitian Hibah Bersaing X Tahun Kedua. Jambi (ID): Universitas Jambi.

Manin F, Hendalia E, Yusrizal, Yatno. 2010. Penggunaan Simbiotik yang Berasal dari Bungkil Inti Sawit dan Bakteri Asam Laktat Terhadap Performans, Lingkungan dan Status Kesehatan Ayam Broiler. Laporan Penelitian Strategi Nasional. Jambi (ID):Universitas Jambi.

Manin F, Hendalia E, Yatno, Rahayu P. 2014. Dampak Pemberian Probiotik Probio_FM Terhadap Status Kesehatan Ternak Itik Kerinci. Jurnal IlmuTernak. 1(2):7-11.

Mathius IW, Azmi, Manurung BP, Sitompul DM, Priyotomo E. 2004. Integrasi sapi-sawit: imbangan pemanfaatan produk samping sebagai bahan dasar pakan. Dalam: Prosiding Seminar Nasional Sistem Integrasi TanamanTernak. Denpasar (ID): 20-22 Juli 2004.

Noel JM. 2003. Processing and by-product. Burotrop Bull. 19: 8.

Novianti, Adriani. 2012. Peningkatan produktivitas sapi Bali yang diberi berbagai bentuk pakan olahan pelepah sawit. Laporan Penelitian Unggulan Perguruan Tinggi. Jambi (ID):Universitas Jambi.

Riza H, Wizna, Rizal Y, Yusrizal. 2015. Peran Probiotik dalam Menurunkan Amonia Feses Unggas. Jurnal Peternakan Indonesia. 17(1): 19-26. https://doi.org/10.25077/jpi.17.1.1926.2015

Rizali A, Fahcrianto, Ansari MH, Wahdi A. 2018. Pemanfaatan limbah pelepah dan daun kelapa sawit melalui fermentasi trichoderma $s p$. sebagai pakan sapi potong. EnviroScienteae Jurnal Ilmiah Pengelolaan Sumberdaya Alam dan Lingkungan. 14(01): 1-7. https://doi.org/ 10.20527/es.v14i1.4886

Tiesnamurti B, Bahri S, Setyadi B, Priyanti A, Yusron A, Dedi SE, Handiwirawan E. 2014. Pedoman pengembangan sistem integrasi sawit-sapi ramah lingkungan. Position paper. Jakarta (ID): Badan Penelitian dan Pengembangan Pertanian.

Yusrizal, Aziz A. 2009. Identifikasi dan Pemanfaatan Kombinasi Berbagai Bakteri untuk menurunkan kadar amonia feses dan litter unggas. Laporan Penelitian Fundamental. Jambi (ID):Universitas Jambi.

Yusrizal, Manin F, Yatn, Noverdiman. 2012. The use of probiotic and prebiotic (symbiotic) derived from palm kernel cake in reducing ammonia emission in the broiler house. In: Proceeding the 1st Poultry International Seminar. Page: 334-343. 